\title{
Photochemical Ligation of DNA Probe prepared in Click Chemistry
}

\author{
Takehiro Ami, Yoshinaga Yoshimura, Tomoya Matsuzaki, and Kenzo Fujimoto*
}

\begin{abstract}
School of Materials Science, Japan Advanced Institute of Science and Technology, 1-1 Asahidai, Nomi, Ishikawa, 923-1292, Japan
\end{abstract}

\begin{abstract}
Template-directed photoligation with 5-carboxyvinyl-2'-deoxyuridine $\left({ }^{\mathrm{CV}} \mathrm{U}\right)$ can be used for genomic research, biotechnology and biomedical agents. However, in photoligation with ${ }^{\mathrm{CV}} \mathrm{U}$, a long photoirradiation time at $366 \mathrm{~nm}$ is required to complete photoligation. To overcome the limitation of photoligation with ${ }^{\mathrm{CV}} \mathrm{U}$, we synthesized new photosensitive probes in the copper-catalyzed azide-alkyne cycloaddition reaction, as the best example of click chemistry.
\end{abstract}

Keyword: DNA, photoligation, click chemistry

\section{Introduction}

DNA ligation methods are important techniques for genomic research, biotechnology and biomedical agents. [1-3] In our previous work, we reported on the template-directed reversible photoligation with 5-carboxyvinyl-2'-deoxyuridine $\left({ }^{\mathrm{CV}} \mathrm{U}\right)$ derivative used as a form of phototriggered DNA manipulation.[4-6] The advantage of using photons as reagents to initiate photoligation is that no additional chemical reagents need to be introduced into the system. However, in photoligation with ${ }^{\mathrm{CV}} \mathrm{U}$, a long photoirradiation time at $366 \mathrm{~nm}$ is required to complete photoligation. To overcome the limitation of photoligation with ${ }^{\mathrm{CV}} \mathrm{U}$, we tried to synthesize new photosensitive probes in click reaction. The copper-catalyzed azide-alkyne cycloaddition reaction, the best example of click chemistry, appears to fulfill the necessity. The reaction was discovered by the groups of Meldal and Sharpless.[7,8] It functions efficiently in aqueous media and produces a 1,2,3-triazole linkage between the two reactants. We hypothesized that the electron-donating properties of the triazole ring might effectively enhance photoligation. And within the field of nucleic acid chemistry, $\mathrm{Cu}(\mathrm{I})$-catalyzed azide-alkyne cycloaddition has been used for labeling oligonucleotides with a range of moieties, such as fluorescein. Thus, we also attempted to synthesize the DNA probe for quick single nucleotide polymorphism (SNP)

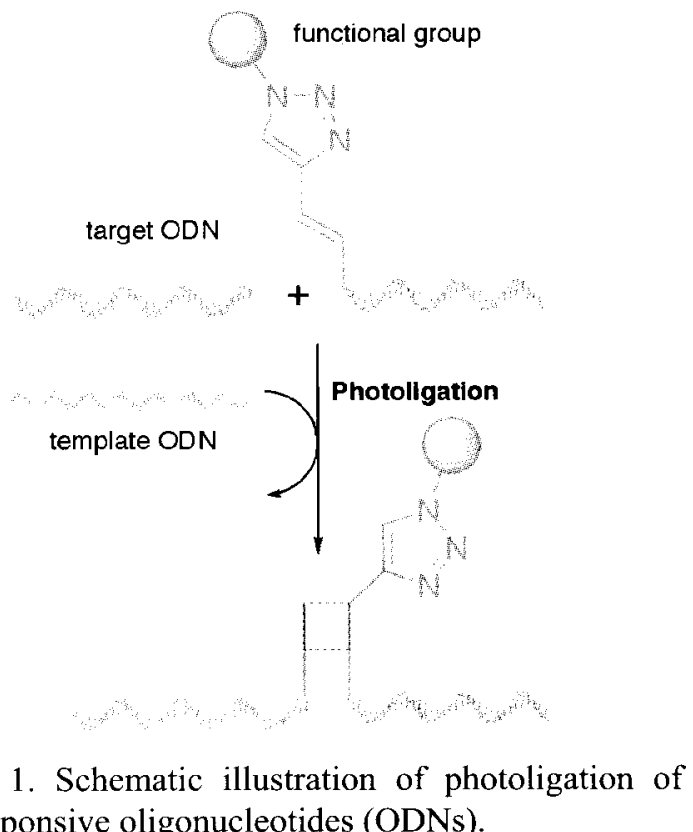
photoresponsive oligonucleotides (ODNs). 
typing using photochemical ligation, as an example.

\section{Experimental}

2.1 General method and materials

${ }^{1} \mathrm{H}$ NMR spectra were measured with Varian Gemini $300(300 \mathrm{MHz})$ spectrometer. ${ }^{13} \mathrm{C}$ NMR spectra were measured with Varian INOVA 500 $(125 \mathrm{MHz})$ spectrometer. Coupling constant $(J$ value) are reported in hertz. The chemical shifts are reported in $\delta(\mathrm{ppm})$ relative to residual $\mathrm{CDCl}_{3}$ $\left(\delta=7.24\right.$ in ${ }^{1} \mathrm{H}$ NMR $), \mathrm{CD}_{3} \mathrm{OD}\left(\delta=3.35\right.$ in ${ }^{1} \mathrm{H}$ NMR, $\delta=49.3$ in ${ }^{13} \mathrm{C}$-NMR) and DMSO- $d_{6}(\delta=$ 2.49 in ${ }^{1} \mathrm{H}$ NMR, $\delta=39.7$ in ${ }^{13} \mathrm{C}$ NMR) as internal standards. Mass spectra were recorded on a Voyager-DE PRO-SF, Applied Biosystems. HPLC was performed on a Chemcobond 5-ODS-H column $(10 \times 150 \mathrm{~mm}, 4.6 \times 150 \mathrm{~mm})$ or a Chemcosorb 5-ODS-H column $(4.6 \times 150 \mathrm{~mm})$ with a JASCO PU-2080 plus, MX-2080-32, DG-2080-53 system equipped with a JASCO UV 2075 detector at $260 \mathrm{~nm}$. The reagents for the DNA synthesizer such as A, G, C, T- $\beta$-cyanoethyl phosphoramidite, and CPG support were purchased from Glen Research. JASCO V-550 UV/VIS spectrophotometer was used for absorption spectra measurements. Photoirradiation was performed by UV-LED (OMURON, $366 \mathrm{~nm}$ ) or $25 \mathrm{~W}$ transilluminator (FUNAKOSHI, TFL-40, $366 \mathrm{~nm}, 5,700 \mu \mathrm{W} / \mathrm{cm}^{2}$ ).

\section{2 (E)-5-(2-Carbomethoxyvinyl)-2'-de ox y -} uridine (2)

5-Iodo-deoxyuridine $(1.00 \mathrm{~g}, 2.82 \mathrm{mmol})$ and $\mathrm{Pd}(\mathrm{OAc})_{2}(0.06 \mathrm{~g}, 0.28 \mathrm{mmol})$ were suspended in DMF $(3 \mathrm{~mL})$ in a $10 \mathrm{~mL}$ glass vial equipped with a small magnetic stirring bar. To this was added the $\mathrm{Bu}_{3} \mathrm{~N}(0.67 \mathrm{~mL}, \quad 2.82 \mathrm{mmol})$ and methylacrylate $(0.38 \mathrm{~mL}, 4.24 \mathrm{mmol})$ and the vial was tightly sealed with an aluminum/Teflon ${ }^{\circledR}$ crimp top. The mixture was then irradiated for four minutes at $100{ }^{\circ} \mathrm{C}$, using an irradiation power of 60 W. After completion of the reaction, the vial was cooled to $50{ }^{\circ} \mathrm{C}$ by gas jet cooling before it was opened. It was then filtered and evaporated in vacuo. The crude was purified by column chromatography $\left(\mathrm{CHCl}_{3} / \mathrm{MeOH}=9 / 1\right)$ to give 2 $(0.84 \mathrm{~g}, 95 \%) .{ }^{1} \mathrm{H}$ NMR (DMSO- $\left.d_{6}, 300 \mathrm{MHz}\right) \delta$ : 11.63 (bs, 1H), 8.40 (s, 1H), 7.36 (d, $1 \mathrm{H}, J=15.5$
$\mathrm{Hz}), 6.84(\mathrm{~d}, 1 \mathrm{H}, J=15.5 \mathrm{~Hz}), 6.12(\mathrm{t}, 1 \mathrm{H}, J=6.3$ $\mathrm{Hz}), 5.24(\mathrm{~d}, 1 \mathrm{H}, J=4.3 \mathrm{~Hz}), 5.15(\mathrm{t}, 1 \mathrm{H}, J=5.3$ $\mathrm{Hz}), 4.24(\mathrm{~m}, 1 \mathrm{H}), 3.79(\mathrm{~m}, 1 \mathrm{H}), 3.67(\mathrm{~s}, 3 \mathrm{H})$, 3.64-3.54 (m, 2H), $2.17(\mathrm{~m}, 2 \mathrm{H})$.

\section{3 (E)-5-(2-Carboxyvinyl)-2'-deoxyuridine (3)}

$2(8.52 \mathrm{~g}, 27.29 \mathrm{mmol})$ was added to $3 \mathrm{M} \mathrm{NaOH}$ (water/ ethanol $=1 / 1,10 \mathrm{ml}$ ) and this mixture stirred at room temperature for $3 \mathrm{~h} . \mathrm{HCl}$ was powered into this solution on cooling ice bath to give white precipitate. The precipitate was filtered and washed with hexane, and sucked dry. The product was dried under vacuum to yield $3(7.24 \mathrm{~g}$, 89\%). ${ }^{1} \mathrm{H}$ NMR (DMSO- $\left.d_{6}, 300 \mathrm{MHz}\right) \delta: 12.16$ (bs, $1 \mathrm{H}), 11.62(\mathrm{~s}, 1 \mathrm{H}), 8.37(\mathrm{~s}, 1 \mathrm{H}), 7.28(\mathrm{~d}, 1 \mathrm{H}, J=$ $15.9 \mathrm{~Hz}), 6.76(\mathrm{~d}, 1 \mathrm{H}, J=15.9 \mathrm{~Hz}), 6.12(\mathrm{t}, 1 \mathrm{H}, J=$ $6.2 \mathrm{~Hz}), 5.25(\mathrm{~d}, 1 \mathrm{H}, J=4.1 \mathrm{~Hz}), 5.18(\mathrm{t}, 1 \mathrm{H}, J=5.1$ $\mathrm{Hz}), 4.24(\mathrm{~m}, 1 \mathrm{H}), 3.79(\mathrm{~m}, 1 \mathrm{H}), 3.60(\mathrm{~m}, 2 \mathrm{H})$, $2.16(\mathrm{~m}, 2 \mathrm{H})$.

\section{$2.4(E)$-5-(2-Bromovinyl)-2'-deoxyuridine (4)}

To a solution of $3(5.00 \mathrm{~g}, 23.5 \mathrm{mmol})$ in $\operatorname{DMF}(100 \mathrm{ml})$ was added $\mathrm{K}_{2} \mathrm{CO}_{3}(4.87 \mathrm{~g}, 35.2$ mmol) at ambient temperature and stirred for 15 minutes. A solution of $N$-Bromosuccinimide $(4.18 \mathrm{~g}$, $23.5 \mathrm{mmol})$ in $\operatorname{DMF}(100 \mathrm{ml})$ was added dropwise over $30 \mathrm{~min}$. The resulting suspension was filtered immediately under suction and the solid was washed well with DMF. The combined filtrate and washing were evapolated to dryness in vacuo to complete remove the DMF and the crude was purified by column chromatography $\left(\mathrm{CHCl}_{3} /\right.$ $\mathrm{MeOH}=9 / 1)$ to give $4(3.94 \mathrm{~g}, 50 \%){ }^{1} \mathrm{H}$ NMR (DMSO- $\left.d_{6}, 300 \mathrm{MHz}\right) \delta: 11.56(\mathrm{~s}, 1 \mathrm{H}), 8.06(\mathrm{~s}$, $1 \mathrm{H}), 7.23(\mathrm{~d}, 1 \mathrm{H}, J=13.6 \mathrm{~Hz}), 6.83(\mathrm{~d}, 1 \mathrm{H}, J=13.6$ $\mathrm{Hz}), 6.11(\mathrm{t}, 1 \mathrm{H}, J=6.6 \mathrm{~Hz}), 5.25(\mathrm{~d}, 1 \mathrm{H}, J=4.4$ $\mathrm{Hz}), 5.09(\mathrm{t}, 1 \mathrm{H}, J=5.2 \mathrm{~Hz}), 4.23(\mathrm{~m}, 1 \mathrm{H}), 3.77(\mathrm{~m}$, $1 \mathrm{H}), 3.57(\mathrm{~m}, 2 \mathrm{H}), 2.12(\mathrm{~m}, 2 \mathrm{H})$.

2.5 (E)-5-(2-trimethylsilyl ethynyl vinyl)-2'deoxy-uridine (5)

A mixture of $4 \quad(3.35 \mathrm{~g}, \quad 10.1 \mathrm{mmol})$, $\mathrm{Pd}\left(\mathrm{PPh}_{3}\right)_{4}(1.17 \mathrm{~g}, 1.01 \mathrm{mmol}), \mathrm{CuI}(0.382 \mathrm{~g}, 2.01$ $\mathrm{mmol})$ and $N, N$-diisopropylethylamine $(8.56 \mathrm{ml}$, $50.4 \mathrm{mmol})$ in $\operatorname{DMF}(50 \mathrm{ml})$ was stirred for 10 minutes. To this there was then added trimethylsilylacetylene $(4.18 \mathrm{ml}, 30.2 \mathrm{mmol})$ and the mixture was stirred for $2 \mathrm{~h}$. The resulting suspension was then filtered and the crude was 
purified by column chromatography $\left(\mathrm{CHCl}_{3} /\right.$ $\mathrm{MeOH}=9 / 1)$ to give $5(2.38 \mathrm{~g}, 67 \%){ }^{1} \mathrm{H}$ NMR $\left(\mathrm{CD}_{3} \mathrm{OD}, 300 \mathrm{MHz}\right) \delta: 8.29(\mathrm{~s}, 1 \mathrm{H}), 6.71(\mathrm{~d}, 1 \mathrm{H}$, $J=16.1 \mathrm{~Hz}), 6.64(\mathrm{~d}, 1 \mathrm{H}, J=16.1 \mathrm{~Hz}), 6.30(\mathrm{t}, 1 \mathrm{H}$, $J=6.5 \mathrm{~Hz}), 4.45(\mathrm{~m}, 1 \mathrm{H}), 3.97(\mathrm{~m}, 1 \mathrm{H}), 3.84(\mathrm{~m}$, $2 \mathrm{H}), 2.32(\mathrm{~m}, 2 \mathrm{H}), 0.21(\mathrm{~m}, 9 \mathrm{H}) ;{ }^{13} \mathrm{C} \mathrm{NMR}$ $\left(\mathrm{CD}_{3} \mathrm{OD}, 125 \mathrm{MHz}\right) \delta: 164.2,151.5,141.0,136.0$, $112.3,109.9,106.5,96.7,89.4,87.2,72.1,62.8$, 42.1 .

$2.65^{\prime}-O-\left(4,4^{\prime}\right.$-Dimethoxytrityl)-(E)-5-(2-trimethylsilyl ethynyl vinyl)-2'-deoxyuridine (6)

To a solution of $5(0.60 \mathrm{~g}, 1.7 \mathrm{mmol})$ in anhydrous pyridine $(10 \mathrm{ml})$ was added $\mathrm{DMTrCl}$ $(0.70 \mathrm{~g}, 2.0 \mathrm{mmol})$ and DMAP( $0.04 \mathrm{~g}, 0.34 \mathrm{mmol})$ at $0^{\circ} \mathrm{C}$. The reaction mixture was stirred for $4 \mathrm{~h}$ at ambient temperature. The reaction mixture was evaporated to dryness under reduced pressure. The crude product was purified by silica gel column chromatography $\left(\mathrm{CHCl}_{3} / \mathrm{MeOH}=97 / 3\right)$ to afford $6(0.34 \mathrm{~g}, 31 \%) .{ }^{1} \mathrm{H}$ NMR $\left(\mathrm{CDCl}_{3}, 300 \mathrm{MHz}\right) \delta$ : 8.61 (bs, 1H), 8.60 (bs, 1H), 7.39-7.24 (m, 9H), $6.83(\mathrm{~m}, 4 \mathrm{H}), 6.58(\mathrm{~d}, 1 \mathrm{H}, J=16.1 \mathrm{~Hz}), 6.30(\mathrm{~m}$, $1 \mathrm{H}), 5.98(\mathrm{~d}, 1 \mathrm{H}, J=16.1 \mathrm{~Hz}), 4.51(\mathrm{~m}, 1 \mathrm{H}), 4.08$ $(\mathrm{m}, 1 \mathrm{H}), 3.78(\mathrm{~s}, 6 \mathrm{H}), 3.74(\mathrm{~s}, 1 \mathrm{H}), 3.40(\mathrm{~d}, 2 \mathrm{H}, J=$ $3.3 \mathrm{~Hz}), 2.46(\mathrm{~m}, 1 \mathrm{H}), 2.26(\mathrm{~m}, 1 \mathrm{H}), 0.16(\mathrm{~m}, 9 \mathrm{H})$; ${ }^{13} \mathrm{C}$ NMR $\left(\mathrm{CD}_{3} \mathrm{OD}, 125 \mathrm{MHz}\right) \delta: 162.0,158.4$, $158.3,149.4,145.0,140.4,136.1,135.6,135.5$, $130.0,129.9,128.1,127.9,127.0,113.4,110.0$, $107.6,105.7,96.0,85.9,85.8,84.7,70.3,64.0$, $56.3,55.2,0.1$.

\section{$2.75^{\prime}-O-\left(4,4^{\prime}\right.$-Dimethoxytrityl)-(E)-5-(2-tri-} methylsilyl ethynyl vinyl)-2'-deoxyuridine phosphoroamidite (7)

To a solution of $6(0.20 \mathrm{~g}, 0.31 \mathrm{mmol})$ in dry $\mathrm{CH}_{3} \mathrm{CN}(5 \mathrm{ml})$ in a sealed bottle was added $0.45 \mathrm{M}$ tetrazole in $\mathrm{CH}_{3} \mathrm{CN}(0.68 \mathrm{ml}, 0.31 \mathrm{mmol})$ and 2-cyanoethyl - $N, N, N^{\prime}, N^{\prime}$-tetraisopropylphosphorodiamidite $(0.097 \mathrm{ml}, 0.31 \mathrm{mmol})$ and the reaction mixture was stirred for $2 \mathrm{~h}$ at ambient temperature. The reaction mixture was diluted with EtOAc and organic layer was washed with a saturated aqueous solution of $\mathrm{NaHCO}_{3}$. The organic layer was collected, dried over anhydrous sodium sulfate, and evaporated to dryness to yield 7 , which was directly used in an automated DNA synthesizer without further purification.

\subsection{Preparation of $\mathrm{ODN}\left({ }^{\mathrm{EV}} \mathrm{U}\right)$}

ODN sequences were synthesized by the conventional phosphoramidite method by using an Applied Biosystems 3400 DNA synthesizer. The coupling efficiency was monitored with a trityl monitor. The coupling efficiency of crude mixture of ${ }^{\mathrm{EV}} \mathrm{U}$ was $97 \%$ yield. The coupling time of crude mixture of ${ }^{{ }^{E V}} U$ was 999 sec. They were deprotected by incubation with $28 \%$ ammonia for $4 \mathrm{~h}$ at $65{ }^{\circ} \mathrm{C}$ and were purified on a Chemcobond 5 -ODS-H column $(10 \times 150 \mathrm{~mm})$ by reverse phase HPLC; elution was with $0.05 \mathrm{M}$ ammonium formate containing $3-20 \% \mathrm{CH}_{3} \mathrm{CN}$, linear gradient (30 $\mathrm{min})$ at a flow rate of $3.0 \mathrm{~mL} / \mathrm{min}$. Preparation of oligonucleotides was confirmed by MALDI-TOF-MS analysis.[9]

\subsection{Huisgen cycloaddition between $\operatorname{ODN}\left({ }^{\mathrm{EV}} \mathrm{U}\right)$ and} azides

A reaction mixture (total volume $2.0 \mathrm{~mL}$ ) containing $\mathrm{ODN}\left({ }^{\mathrm{EV}} \mathrm{U}\right)(50 \mu \mathrm{M}$ strand conc. $)$, a solution of an azide in EtOH (2.5 mM), a aqueous solution of $\mathrm{CuSO}_{4}(2 \mathrm{mM})$ and a aqueous solution of sodium ascorbate (1 mM) was shaken for $12 \mathrm{~h}$. The crude product was were purified on a Chemcobond 5-ODS-H column $(10 \times 150 \mathrm{~mm})$ by reverse phase HPLC; elution was with $0.05 \mathrm{M}$ ammonium formate containing 3-20\% $\mathrm{CH}_{3} \mathrm{CN}$, linear gradient $(30 \mathrm{~min})$ at a flow rate of $3.0 \mathrm{~mL} /$ $\min$.

\subsection{Template-directed photoligation}

A reaction mixture (total volume $200 \mu \mathrm{l}$ ) containing $\mathrm{ODN}(\mathrm{T}) \quad(10 \mu \mathrm{M}$ strand conc.), photoligation probe $(10 \mu \mathrm{M}$ strand conc.) and ODN $(6 \mathrm{~A})(12 \mu \mathrm{M}$ strand conc.) in $50 \mathrm{mM}$ sodium cacodylate buffer $\left(\mathrm{pH} \mathrm{7.0)}\right.$ was irrasiated a $0{ }^{\circ} \mathrm{C}$ with UV-LED (366 nm). After irradiation $10 \mu \mathrm{L}$ of the aliquot was taken up and subjected to HPLC analysis. Analysis was carried out on a Chemcobond 5-ODS-H column $(4.6 \times 150 \mathrm{~mm})$, detected at $260 \mathrm{~nm}$; elution was with $0.05 \mathrm{M}$ ammonium formate containing 5-8\% acetonitrile, linear gradient $(20 \mathrm{~min})$, then $8-30 \%$ acetonitrile, linear gradient $(20 \mathrm{~min})$ at a flow rate of $1.0 \mathrm{ml} /$ min. Irradiation at $366 \mathrm{~nm}$ caused the ligated product. They were characterized by MALDI-TOF-MS [10]. 


\section{Results and Discussion}

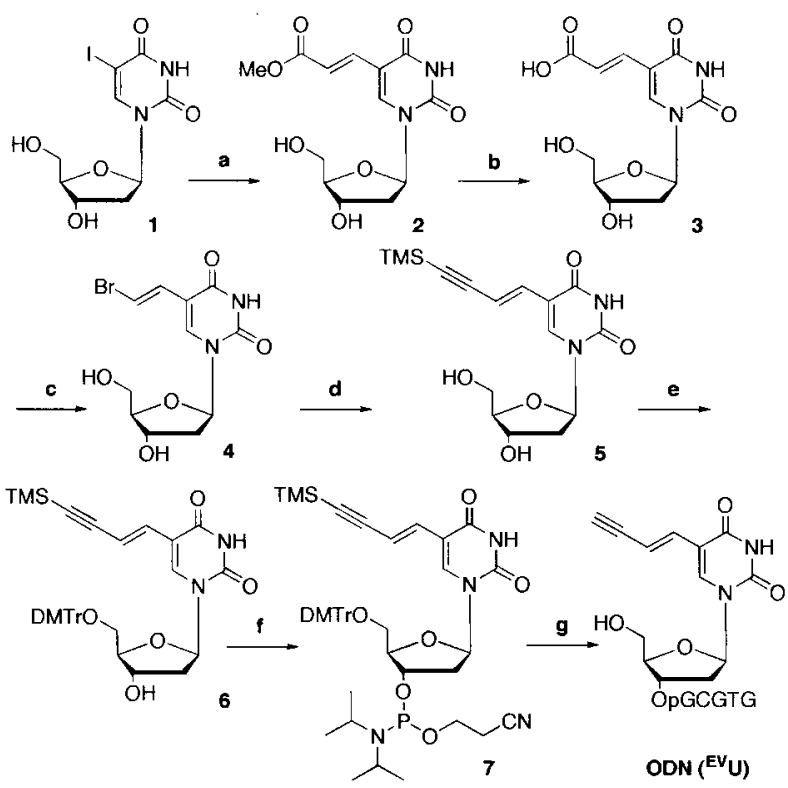

Scheme 2. Reagents and conditions: (a) $\mathrm{Pd}(\mathrm{OAc})_{2}$, $\mathrm{Bu}_{3} \mathrm{~N}$, methylacrylate, DMF, $100{ }^{\circ} \mathrm{C}, 4 \mathrm{~min}, 95 \%$; (b) $\mathrm{NaOH}$, water/ethanol $=1 / 1, \mathrm{rt}, 3 \mathrm{~h}, 89 \%$; (c) $\mathrm{K}_{2} \mathrm{CO}_{3}$, $N$-bromosuccinimide, DMF, rt, $30 \mathrm{~min}, 50 \%$; (d) $\mathrm{Pd}\left(\mathrm{PPh}_{3}\right)_{4}, \quad \mathrm{CuI}, \quad N, N$-diisopropylethylamine, trimethylsilylacetylene, $\quad \mathrm{rt}, \quad 2 \mathrm{~h}, \quad 67 \%$; (e) 4,4'-dimethoxytrityl chloride, DMAP, pyridine, $\mathrm{rt}, 4 \mathrm{~h}$, $31 \%$; (f) $\left(i \mathrm{Pr}_{2} \mathrm{~N}\right)_{2} \mathrm{PO}\left(\mathrm{CH}_{2}\right)_{2} \mathrm{CN}, 1 H$-tetrazole, $\mathrm{CH}_{3} \mathrm{CN}$, rt, $2 \mathrm{~h}$, quant.; (g) DNA synthesizer.

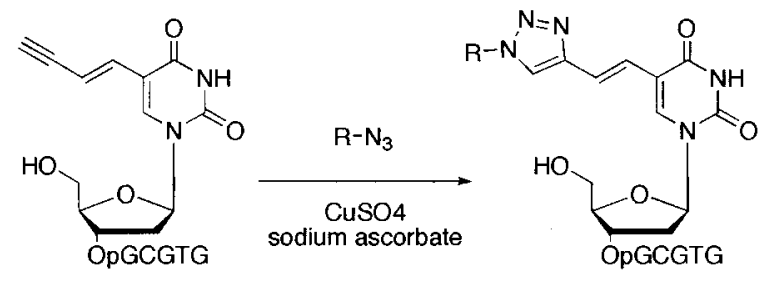

$$
\text { ODN }\left(\mathrm{CV}^{\mathrm{O}} \mathrm{U}\right): \mathrm{R}=\mathrm{EONH}
$$

Scheme 3. Synthesis of photoresponsive ODNs.

The nucleoside phosphoramidite of 5-ethynylvinyl-2'-deoxyuridine $\left({ }^{\mathrm{EV}} \mathrm{U}\right)$ was prepared (Scheme 2), and this monomer was incorporated into ODN using standard automated DNA synthesis protocols. After deprotection and purification of the oligomer, containing ${ }^{\mathrm{EV}} \mathrm{U}$, four azides were purchased and synthesized according to a method reported in the literature[11]. Huisgen cycloaddition between $\mathrm{ODN}\left({ }^{\mathrm{EV}} \mathrm{U}\right)$ and azides was carried out. After purification of the products, photoresponsive ODNs (Scheme 3) were characterized by MALDI-TOF-MS.[10]

$$
\begin{aligned}
& \text { ODN }\left({ }^{C V} U\right) \quad 5^{\prime}-{ }^{C V} V_{U G C G T G-3 '} \\
& \text { ODN( }\left(^{\mathrm{BTV} U}\right) \quad 5^{\prime} \mathrm{B}^{\mathrm{BTV}} \text { UGCGTG-3' } \\
& \text { ODN(PTV }{ }^{\text {PT) }} \quad 5^{\prime} \text { PTV }_{\text {UGCGTG-3' }} \\
& \text { ODN(MPTVU) 5'-MPTVUGCGTG-3' } \\
& \text { ODN( } \left.{ }^{N T V_{U}}\right) \quad 5^{\prime-N T V} \text { UGCGTG-3' } \\
& \text { ODN }{ }^{\text {BNTVU}} \text { ) } \quad 5^{\prime} \text { - BNTV UTCAGTGTA-3' } \\
& \text { ODN(T) 5'-TGTGCT-3' } \\
& \text { ODN(6A) 5'-CACGCAAGCACA-3' } \\
& \text { Capture ODN 5'-NH } \text { - }_{2} \text {-SSSS-ACTCACAGTTTTCAC-3' } \\
& \begin{array}{lr} 
& \text { 5'-GGAGTGGCCGGGAGTTGGGCGAGTA } \\
\text { ODN(WT) } & \text { CGGGCTGCAGGCATACACTGAAGTGA } \\
& \text { AAACTGTGAGTGTGGGACCTGCTGGG }
\end{array} \\
& \begin{array}{l}
\text { AAACTGTGAGTGTGGGACCTGCTGGG } \\
\text { GGCTCAGGGCCTGTTGGGGCTTG } 3^{\prime}
\end{array} \\
& \begin{array}{lr}
\text { ODN(MUT) } & \text { 5'-GGAGTGGCCGGGAGTTGGGCGAGTA } \\
\text { CGGGCTGCAGGCATACACTAAAGTGA } \\
\text { AAACTGTGAGTGTGGACCTGCTGGG }
\end{array} \\
& \begin{array}{l}
\text { AAACTGTGAGTGTGGGACCTGCTGGG } \\
\text { GGCTCAGGGCCTGTTGGGGCTTG-3' }
\end{array}
\end{aligned}
$$

Figure 1. ODNs used in this study. Bold bases indicate the SNP site.

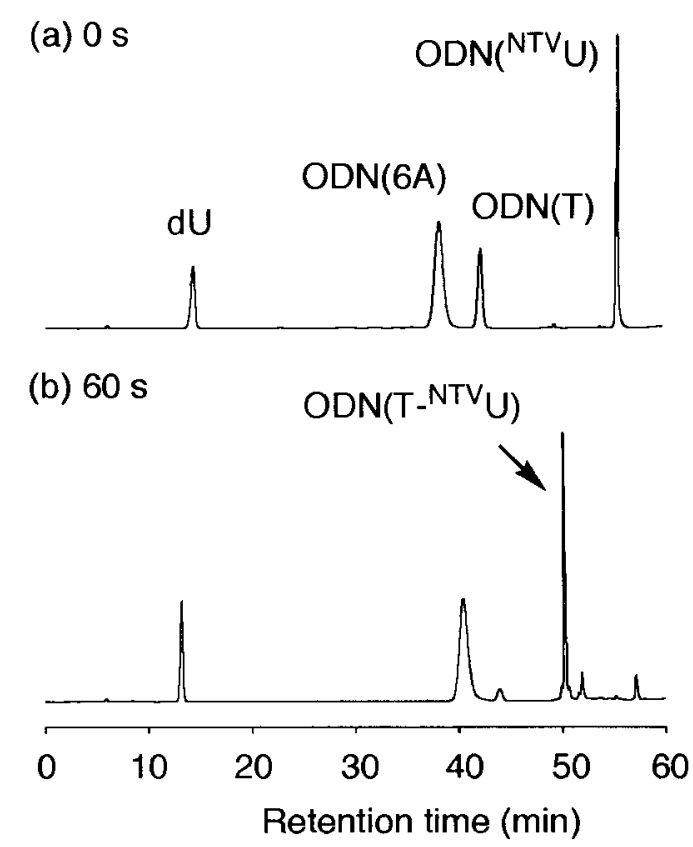

Figure 2. HPLC analysis of photoligation with $\operatorname{ODN}\left({ }^{\mathrm{NTV}} \mathrm{U}\right)$ and $\mathrm{ODN}(\mathrm{T})$ in the presence of $\operatorname{ODN}(6 \mathrm{~A})$. 
We determined the feasibility of photoligation of the ODNs containing a triazole ring and $\operatorname{ODN}(\mathrm{T})$ in the presence of $\operatorname{ODN}(6 \mathrm{~A})$. It is also shown that the photoligation rates with ODNs containing a triazole ring are more rapid than the photoligation rates with $\mathrm{ODN}\left({ }^{\mathrm{CV}} \mathrm{U}\right)$. The time in which the photoligation rates reached the $42 \%$ conversion in $5 \mathrm{sec}$ (Figure 3). Photoligation on the second time scale becomes possible with NTVU.

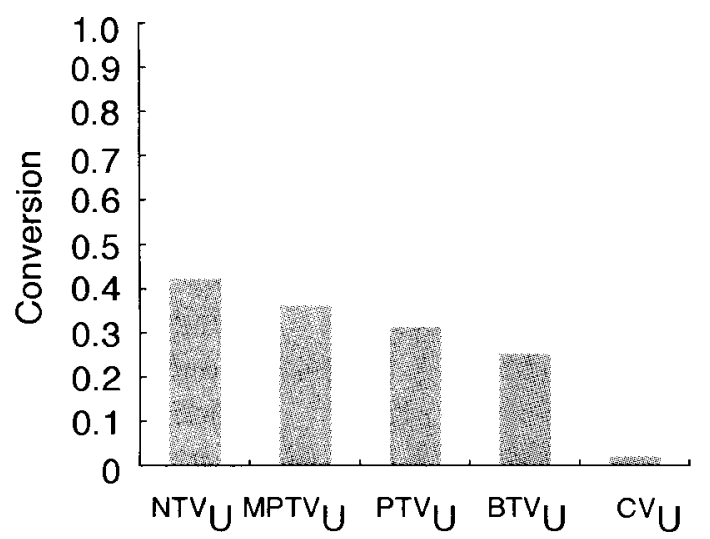

Figure 3. Photoligation yield obtained by photoirradiation at $366 \mathrm{~nm}$ for $5 \mathrm{~s}$ by using photoresponsive ODNs.

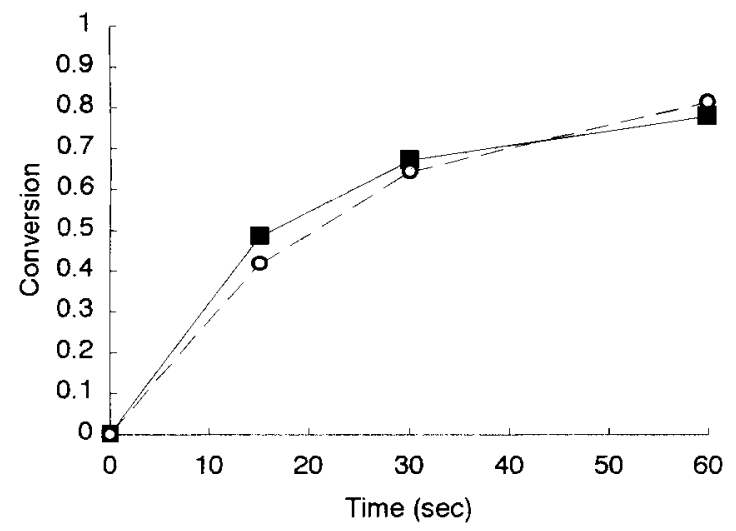

Figure. 4 Comparison of photoligation rates with ODN $\left({ }^{\mathrm{NTV}} \mathrm{U}\right)$. Open circle symbols represent ODN(T) that had been photoligated, and filled square symbols denote ODN $(C)$ that had been photoligated.

There was a difference between the photoligation rates by using $\mathrm{ODN}\left({ }^{\mathrm{CV}} \mathrm{U}\right)$ with 3 '-terminal $\mathrm{T}$ and the photoligation rates by using $\mathrm{ODN}\left({ }^{\mathrm{CV}} \mathrm{U}\right)$ with 3 '-terminal $\mathrm{C}$. Thus, it was necessary to change handling procedures depending on the target of photoligation. But, there was little different between the photoligation rates by using $\mathrm{ODN}\left({ }^{\mathrm{NTV}} \mathrm{U}\right)$ with 3 '-terminal $\mathrm{T}$ and the photoligation rates by using $\operatorname{ODN}\left({ }^{\mathrm{NTV}} \mathrm{U}\right)$ with 3 '-terminal C. Thus, it is not necessary to change handling according to depending on the target of photoligation. Therefore photoligation by using $\mathrm{ODN}\left({ }^{\mathrm{NTV}} \mathrm{U}\right)$ is very simple and easy.

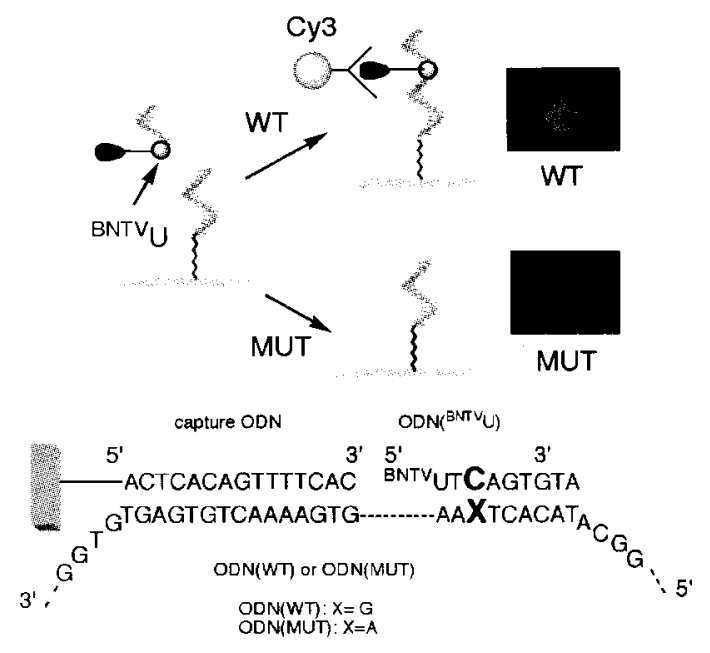

Figure 5. Strategy and fluorescence images for the detection of single nucleotide differences on a DNA chip.

To show that this new photosensitive ODN probe is suitable for practical use, we performed a quick SNP typing as an example. We synthesized naphtyl azide containing biotin, and Huisgen cycloaddition between the azide and ODN $\left({ }^{\mathrm{EV}} \mathrm{U}\right)$ was carried out. After purification of the products, ODN $\left({ }^{\mathrm{BNTV}} \mathrm{U}\right)$ was characterized by MALDI-TOF-MS.[12] We constructed the DNA chip by attaching amino-labelled ODN (capture ODN), onto the aldehyde-modified glass surface. A glass chip spotted with $2 \mathrm{mM}$ target, ODN (WT) or ODN (MUT) and ODN ( $\left.{ }^{\mathrm{BNTV}} \mathrm{U}\right)$ was irradiated at $366 \mathrm{~nm}$ for $10 \mathrm{~min}$ in $50 \mathrm{mM}$ sodium cacodylate buffer (pH 7.0) (Figure 5). After the chip had been washed with deionized water at $98^{\circ} \mathrm{C}$ for $5 \mathrm{~min}$, a phosphate-buffered saline (PBS) solution of strept-avidin-Cy3 conjugate was added to the surface, and the chip was washed twice in PBS. Fluorescence signals were detected on a micro array scanner. As shown in Figure 5, we measured the strong fluorescence signal of the photoligated 
product with the completely complementary case, showing a measured rate that was $10^{3}$-fold higher than that of the case with a single mismatch in the target sequence.

\section{Conclusion}

In summary, we performed the rapid and efficient synthesis of new photosensitive probes in the copper-catalyzed azide-alkyne cycloaddition reaction. Photoligation with these probes proceeds very quickly (second time scale). We also performed quick SNP typing with a photochemical probe in which biotin was incorporated in click chemistry. The reactivity of these probes will be beneficial to in situ DNA manipulation.

\section{References}

1. a) A. Marshall, J. Hodgson, Nature Biotechnol, 16 (1998) 27. b) G. Ramsay, Nature Biotechnol, 16 (1998) 40. c) G. C. King, D. A. Giusto, W. A. Wlasoff, S. Giesebrecht, E. Flening, G. D. Tyrelle, Human Mutation, 23 (2004) 420. d) D. A. Hinds, L. L. Sture, G. B. Nilson, E. Halpeerin, E. Eskin, D. G. Ballinger, K. A. Frazer, D. R. Cox, Science, 307 (2005) 1072.

2. a) E. Beyever, P. Iversen, L. Smith, J. Spinolo, G. Zon, Antisense Res Dev., 2 (1992) 109. b) W. Roush, Science, 276 (1997) 1192.

3. a) R. E. Christffersen, Nature Biotechnol., 15 (1997) 483. b) S. I. Letovsky, R. W. Cottingham, C. J. Porter, P. W. D. Li, Nucleic Acids Res., 26 (1998) 94.

4. a) K. Fujimoto, S. Matsuda, N. Takahashi, I.
Saito, J. Am. Chem. Soc., 122 (2000) 5646. b) Y. Yoshimura, Y. Noguchi, H. Sato, K. Fujimoto, CHEMBIOCHEM, 7 (2006) 598. c) S. Ogasawara, K. Fujimoto, Angew. Chem. Int. Ed., 45 (2006) 1.

5. M. Ogino, Y. Yoshimura, A. Nakazawa, I. Saito, K. Fujimoto, Org. Lett., 7 (2005) 2853.

6. a) S. Ogasawara, K. Fujimoto, CHEMBIOCHEM, 6 (2005) 1756. b) M. Ogino, D. Okamura, K. Fujimoto, STAM, 8 (2007) 318.

7. C. W. Tornoe, C. Christensen, M. Meldal, $J$. Org. Chem., 67 (2002) 3057.

8. V. V. Rostovtsev, L. G. Green, V. V. Fokin, K. B. Sharpless, Angew. Chem. Int. Ed., 41 (2002) 2596.

9. MALDI-TOF MS: Calcd. for $\mathrm{ODN}\left({ }^{\mathrm{EV}} \mathrm{U}\right)\left[(\mathrm{M}+\mathrm{H})^{+}\right]$1859.35, found 1859.41

10. MALDI-TOF MS: Calcd. for $\mathrm{ODN}\left({ }^{\mathrm{BTV}} \mathrm{U}\right)\left[(\mathrm{M}+\mathrm{H})^{+}\right]$1992.41, found 1992.37, MALDI-TOF MS: Calcd. for $\operatorname{ODN}\left({ }^{\mathrm{PTV}} \mathrm{U}\right)\left[(\mathrm{M}+\mathrm{H})^{+}\right]$1978.40, found 1978.42, MALDI-TOF MS: Calcd. for $\mathrm{ODN}\left({ }^{\mathrm{MPTV}} \mathrm{U}\right)\left[(\mathrm{M}+\mathrm{H})^{+}\right] \quad$ 2008.41, found 2008.45, MALDI-TOF MS: Calcd. for $\mathrm{ODN}\left({ }^{\mathrm{NTV}} \mathrm{U}\right)\left[(\mathrm{M}+\mathrm{H})^{+}\right] 2028.41$, found 2028.39 .

11. a) C. B. Reese, Q. Song, Nucleic Acids Res. 27 (1999) 2672. b) S. Carriero, M. J. Damha, Org. Lett., 5 (2003) 273.

12. MALDI-TOF MS: Calcd. for $\mathrm{ODN}\left({ }^{\mathrm{BNTV}} \mathrm{U}\right)\left[(\mathrm{M}+\mathrm{H})^{+}\right] \quad 3299.74, \quad$ found 3299.81 